\title{
Building FL-Vocabulary Transferability through Semantic Boggle
}

\author{
Fitriani Halimah'), Lidiyatul Izzah') \\ 1) SMPN 77 Jakarta, Indonesia \\ 2) Universitas Muhammadiyah Jakarta, South Tangerang, Banten, Indonesia \\ Fitrianihalimah08@gmail.com
}

\begin{abstract}
The purpose of this study was to investigate the effectiveness of the Semantic Boggle Game on building vocabulary transferability in foreign language students. The study was conducted in SMPN 177 Jakarta. The population in this study was all seventh-graders of which 7E of 35 students as the sample representative. The method used in this study was a quantitative method with a pre-experimental research design. In collecting the data, the writer used the students' pre-test and post-test. The data result indicates that the total students' pre-test scores are 2085 with an average score of 59,57. The total student's post-test score is 2745 with an average of 78,68. The results of the pre-test and post-test were calculated using a t-test. The calculation of the data result indicates that the t-count was 2,26 with $t$-table is 1,69 at the 0,05 significance level. Therefore, this implies that the alternative hypothesis $\left(\mathrm{H}_{1}\right)$ is accepted and the null hypothesis $\left(\mathrm{H}_{0}\right)$ is rejected. The writers then concluded that using Semantic Boggle Game in teaching vocabulary is effective to build students' vocabulary transferability.
\end{abstract}

Keywords: Semantic Boggle Game, game-based learning, vocabulary transferability Citation APA Style: Halimah, F., \& Izzah, L. (2020). Building FL-Vocabulary Transferability through Semantic Boggle. English Language in Focus (ELIF), 2(2), 79-86.

\section{INTRODUCTION}

$\mathrm{L}$ language is a skill that most people need to communicate with. Not only to communicate, but also to build relationships between other countries. By using language, people can say what they want to show and share. At this time, every country must learn English in or out of school. English is now important to learn because it is a universal language widely used by many countries in various fields, interests, and situations. Besides the four basic competencies, students must learn other aspects that support four skills, including grammar, vocabulary, and pronunciation.

Vocabulary learning is crucially important for foreign language transferability. As Wilkins (1972) said in Zhang, Song, \& Burston (2011), "without grammar very little can be conveyed, without vocabulary, nothing at all can be conveyed" (p. 111). Vocabulary is the basis of English language learning. This is 
an aspect that supports four skills at once. Ghorbani \& Rahmandoost (2012) defined vocabulary as a key component of language mastery and provides many foundations for how learners speak, listen, read, and write. Meanwhile Alqahtani (2015) stated that vocabulary is a list of words with meanings. If students are unable to understand the meaning and use of vocabulary positively, it can lead to an ineffective communication process.

Mastering vocabulary is not easy. At school, many students lack vocabulary. They only understand words that are used in daily life and do not understand foreign words in English. Therefore, teachers must provide good teaching by presenting materials with a suitable teaching technique in the classroom, so that the students easily understand the lesson. This is supported by Sahrawi (2016) that the teachers should find the best way to present the material, especially vocabulary. They must be creative in choosing media and teaching techniques, so students can be interested in learning English and dealing with their problems.

The use of Games in teaching will help learners during their language learning. With games, it can make a class entertaining and build students' interest. This can provide intense and meaningful language practice, then they should be considered as centers of language teacher's repertoire and not merely a way of passing the time (Bakhsh, 2016; Saputra \& Hadi, 2019; Wright, Betteridge, \& Buckby, 2006). Using games in teaching vocabulary helps learners to assimilate words. This process is influenced by the number of times learners are exposed to a word and its different definitions. If words are not exercised, they do not end up in longterm memory and are easily forgotten (Carter \& Mccarthy, 2014).

However, Ferčec, LiermannZeljak, \& Lenard (2019) suggest that there are several factors teachers have to bear in mind and be careful about when selecting games or any similar (online) engaging activity, e.g., which game or activity should be used and when, how it could relate to the syllabus, textbook, topic, or context, and to what extent it is beneficial for students. Most researchers agree that special emphasis should be placed on how games and engaging activities are to be tailored to specific language learning contexts and students' needs or adapted to suit the content of the curriculum, complementing at the same time regular classroom activities, enhancing the existing lesson materials, enriching paper-based activities, boosting learner autonomy, and adding an element of surprise (Loukas \& Ioannis, 2018).

In educational contexts, not only learners need to be able to enter the world of the game, but also be critical about the process, to be able to reflect upon their relationship with the game when viewed from outside. This suggests that creative learning through gaming requires substantial efforts from teachers, to achieve positive results (AlAzawi, Al-Faliti, \& Al-Blushi, 2016). Therefore, one of the games that can be used by the teacher is the vocabulary semantic Boggle Game. Semantic Boggle is a serious game that exercises vocabulary. It is based on the traditional word-guessing game, but it brings 
educational value by identifying semantically related words. Semantic Boggle Game or commonly known as word search game (Toma, Alexandru, Dascalu, Dessus, \& Trausan-Matu, 2017). It is a word game in which players connect neighboring letters in a $4 \times 4$ grid. The player who finds the longest words wins the game. This is a board game, played for fun, but it can be added educational value by looking for specific words or relations between words.

According to Toma et al (2017), semantic Boggle can be used in a minimalistic web application, where the user forms words by selecting letters from the $4 \times 4$ grid. The current word is sent to the Reader-Bench web server together with the seed to compute a semantic similarity score. This latter value is then added to the initial score. For keeping track of the used words, checked words are available in the list under Used Words and are high- lighted based on the similarity with the seed (see Fig. 1)

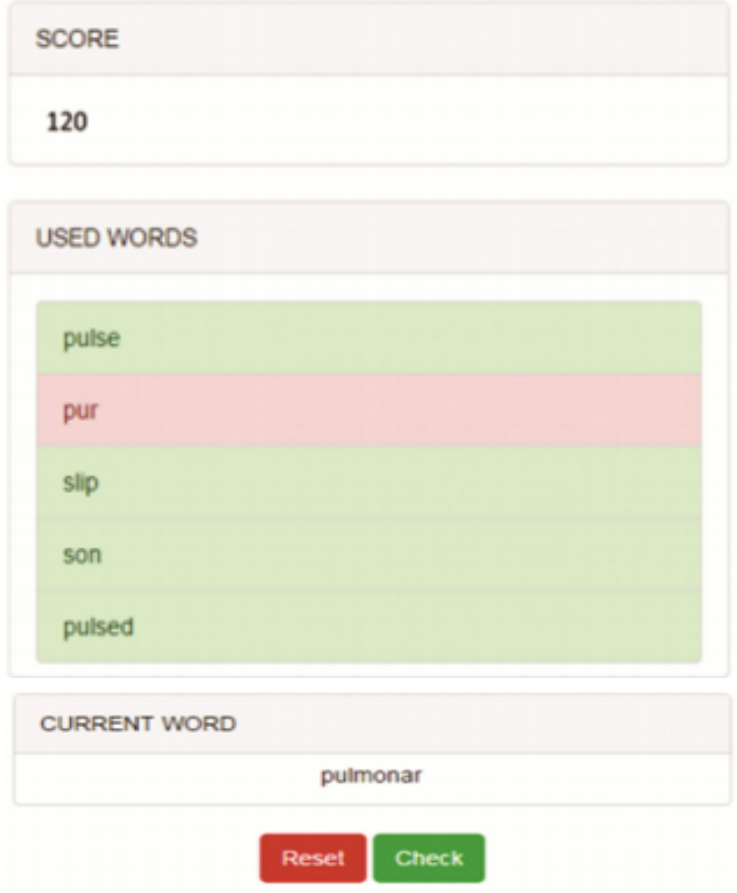

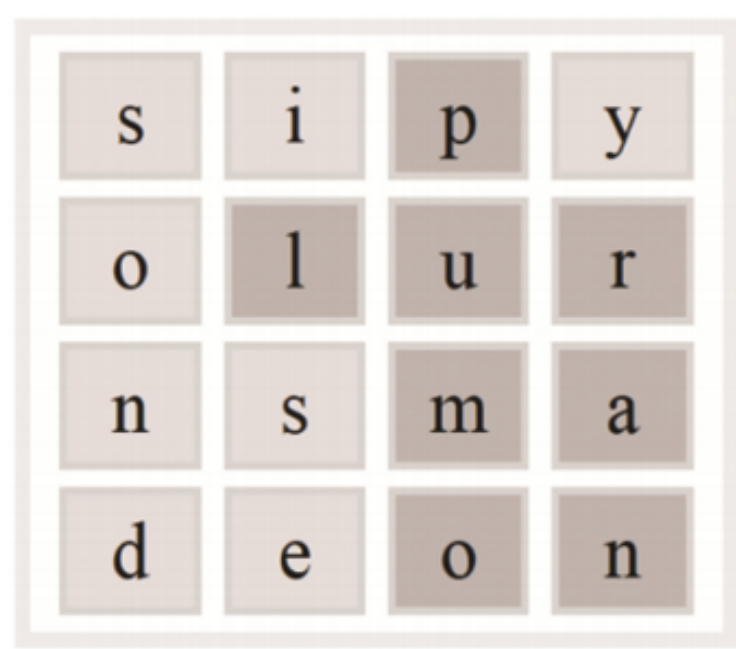

Figure 1. Semantic Boggle - Gameplay print-screen.

However, because of the research limitation, the game in this study will be limited to the traditional game. In implementing the Semantic Boggle Game, The first step that should be looked at by the teacher is to create the preparation of material. The teacher prepares a lesson plan for the learning process using Semantic Boggle Game. A lesson plan is a guide for the teacher to teach students in the classroom. In the class, the teacher delivers the material and then tries to play the Semantic Boggle Game. Before the game starts, the teacher tells the students how to play the game using Semantic Boggle Game. The teacher should prepare the media of Semantic Boggle Game consists of the instructions and clues. After the teacher selects the materials, the teacher requires preparing the media. Because of Semantic Boggle Game printed on HVS paper, the teacher should print the game based on the total groups in the class. Besides, the teacher asks students to prepare their pencil or pen to answer the clues.

Huyen in Al-Furqon(2017) said that Semantic Boggle game or word 
search games have been shown to have advantages and effectiveness in learning vocabulary in various ways. Teaching vocabulary through Semantic Boggle Game provides all materials needed by the students such as the exercises to improve spelling, word understanding, pronunciation, and so on. Semantic Boggle games can also be an option technique of teaching to make the students feel fun in learning English vocabulary. The teacher also gets benefits to conduct the lesson effectively. The students may be happy and interested in learning and they always try to upgrade their vocabulary from Semantic Boggle game.

\section{RESEARCH METHODOLOGY}

Degarding the main aim of this $\mathrm{R}$ study to investigate the effectiveness of the Semantic Boggle Game in building vocabulary transferability in foreign language students, The method used in this study is quantitative. Bowling in Al-Sabbah (2015) stated that Quantitative research methods use techniques that include hypotheses, examine relationships between independents and dependent variables and measure the percentages and frequencies of observations. The quantitative method is research that explains phenomena, which used the numerical data analyzed statistically.

In this study, the writer used quantitative with the pre-experimental design of one group-pretest post-design to compares the students learning achievement before and after the treatments. There were two variables in this study, independent variable and dependent variable. According to
Creswell (2009) Independent variables (X) are the variables that might cause, influence, or affect the outcome. On the other hand, dependent variables $(\mathrm{Y})$ are variables that depend on the independent variables. The writer determined using Semantic Boggle Game as variable $\mathrm{X}$ and FL-Vocabulary transferability as variable $Y$.

In collecting the data, both pretests and post-tests were used as the instrument. The research was conducted on those tests and post-tests in SMP Negeri 177 Jakarta, which is located on Jl. Raya Kodam Bintaro, South Jakarta in the academic year of 2019/2020. The population of the study is the seventhgrade students of SMP Negeri 177 Jakarta. The selected population then narrowed into a sample. In selecting the sample, the writers chose a cluster random sampling and the sample was class of 7E, in which the class consisted of 35 students.

In conducting the treatments, the researchers acted as the teacher and the judge of Semantic Boggle game at the same time. There are some steps for implementing the Semantic Boggle Game. First, the student needs to prepare the equipment before the game starts, such as a pencil or pen. Second, the teacher instructs how to play this game. The teacher asks students to make a group consists of four or five persons. Third, the teacher gives the groups a paper of Semantic Boggle Game and there are random words in a box. Fourth, the teacher tells all of the groups about the clues below the word box. Fifth, every group must find as many words as possible according to the clues given by the teachers. Sixth, the teacher gives 15 
until 20 minutes to finish this game. Finally, the groups who find the most words are the winner of this game.

In administering the test, the pretest was administered to measure students' prior knowledge. In the end after treatments were done, a post-test was held to investigate whether there is a significant difference in students' vocabulary transferability before and after implementing of Semantic Boggle game. The test used in this study was a multiple-choice test. After the data from pre-test and post-test has been collected, the researchers then analyzed the output data by using statistic calculation of the independent t-test formula to determine whether there are significant differences between the means of the sample before and after using Semantic Boggle game in teaching vocabulary. All submissions were performed on significance level 0 , 05 .

In this study, the dependent t-test was calculated using SPSS for Windows Program. After getting the $\mathrm{t}$-value ( $\mathrm{t}$ obtained), then it was compared with the $t$ critical. If the $t$-obtained $>t$-critical at the level of significance $(p)=0,05$, then the null hypothesis (Ho) is rejected and accepts the alternative hypothesis (Ha). If the obtained $<\mathrm{t}$-critical then the null hypothesis is accepted.

\section{FINDING AND DISCUSSION}

fter the data was collected, the
writer analyzed the data gained from the research. Based on the research finding, it showed that the scores of the pre-test and post-test gave significant differences. The lowest score of the pre-test is 45 and the highest score of the pre-test is 90 . Then, the lowest score of the post-test is 65 and the highest score of the post-test is 100 . The average of students' scores in the pretest is 59,57 and in the post-test is 78,68 .

The following diagram presents the distribution frequency of students' pre-test and post-test score of experimental class:

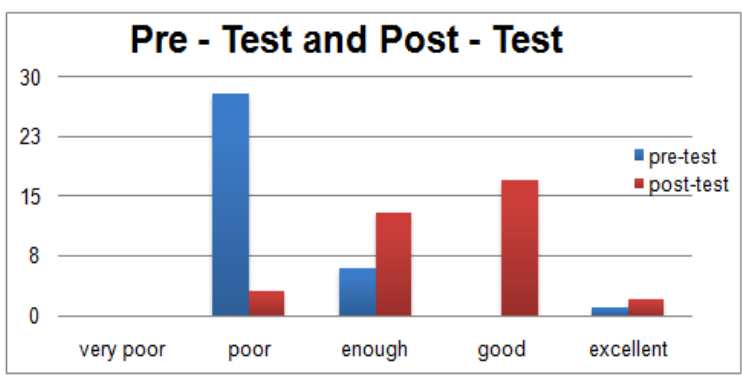

Diagram 1. The Score of Pre-Test and Post-Test of Experimental Class

Based on the diagram above, in administering-test, it reveals that only one student that was in the excellent criteria $(2,857 \%)$, six students were in enough criteria $(17,142 \%), 28$ students were in the poor criteria (80\%), and no one student was good and very poor criteria. For post-test reveals that two students were in the excellent criteria $(5,714 \%), 17$ students were in good criteria (48,571\%), 13 students were in enough criteria (37,142\%), three students were in the poor criteria $(8,571 \%)$, and no one student was in very poor criteria.

In addition, referring to the finding of score calculation using a t-test, the t-test calculation showed that $t_{\text {calculation }}$ was 2,26 with a degree of freedom (df) of 35. In sum, comparing to the significance level of 0,05 with table 1,69 , the data analysis finding showed that $t_{\text {calculation }}$ is higher than $t_{\text {table. It }}$ indicates that Semantic Boggle Game 
gives significant effect to build vocabulary transferability on the foreign language learner.

\section{CONCLUSION}

$\mathrm{R}$ eferring to the finding of the study about the effectiveness of Semantic Boggle Game in building students' FL-vocabulary transferability, the result of the post-test shows that the main score of the vocabulary test is higher than pretest. In sum, the implementation of Semantic Boggle Game experimentally has a positive effect on the students in building their foreign language vocabulary. Based on the data that has been taken by the researchers, the value of $t_{\text {calculation }}(2,26)$ was higher than the value of $t_{\text {table }}(1,69)$ at the significance level of 0,05 . It means that there is a significant difference between teaching vocabulary through Semantic Boggle Game and teaching vocabulary without Semantic Boggle Game. Therefore, teaching vocabulary through Semantic Boggle Game is effective to build students' FL-vocabulary transferability. This game gives a significant effect on the students of seventh graders of SMPN 177 Jakarta.

\section{REFERENCES}

Al-Azawi, R., Al-Faliti, F., \& Al-Blushi, M. (2016). Educational Gamification Vs. Game-Based Learning: Comparative Study. International Journal of Innovation, Management, and Technology, 7(4), 132-136. Retrieved from DOI: 10.18178/ijimt.2016.7.4.659

Al-Furqon, A. S. (2017). The Effect of Word Search Puzzle Game in Teaching Vocabulary to the First Grade students of SMPN 3 Proppo.
Wacana Didaktika, 5(2), 101. Retrieved from https://doi.org/10.31102/wacanadi daktika.v5i02.25

Al-Sabbah, S. (2015). The Applications of Qualitative and Quantitative Research among Academic Staff in Psychology and Education: A Review of Practice. International Journal of Education and Research, 3(3), 715726. Retrieved from www.ijern.com

Alqahtani, M. (2015). The Importance of Vocabulary in Language Learning and How to be Taught. International Journal of Teaching and Education, 3(3), 21-34.

Bakhsh, S. A. (2016). Using Games as a Tool in Teaching Vocabulary to Young Learners. English Language Teaching, 9(7), 120-128. Retrieved from https://eric.ed.gov/?id=EJ1101751

Carter, R., \& Mccarthy, M. (2014). Vocabulary and Language Teaching. New York: Taylor and Francis.

Creswell, J. W. (2009). Research Design Qualitative, Quantitative, and Mixed Methods Approaches. London: SAGE Publications, Inc.

Ferčec, I., Liermann-Zeljak, Y., \& Lenard, D. L. (2019). Games and Engaging Activities in the ESP/EAP Classroom. In K. Divini (Ed.), Options, Practices and Possibilities of EAP and ESP Practitioners. E-locus University of Crete Institutional Repository.

Ghorbani, M. R., \& Rahmandoost, M. (2012). Higher Task-induced Involvement Load Enhances Students' EFL Vocabulary Learning. Article in Journal of Language Teaching and Research, 3(6), 12021207.

https://doi.org/10.4304/jltr.3.6.120 2-1207 
Loukas, M., \& Ioannis, T. (2018). Game as a Learning Tool in Environmental Education. International Journal of Innovation and Research in Educational Sciences, 5(6), 23495219.

Sahrawi. (2016). The Effectiveness of Mind Mapping for Teaching Vocabulary to the Eighth Grade Students of SMP Negeri 3 Sungai Kakap in Academic Year 2012/2013. Jurnal Pendidikan Bahasa, 2(2), 236247.

https://doi.org/10.31571/BAHASA. V2I2.246

Saputra, H. N., \& Hadi, M. S. (2019). Teaching Vocabulary through Fly Swatter Game. English Language in Focus (ELIF), 2(1), 17-24. Retrieved from

https://jurnal.umj.ac.id/index.php/ ELIF/article/view/4829/3356
Toma, I., Alexandru, C.-E., Dascalu, M., Dessus, P., \& Trausan-Matu, S. (2017). Semantic Boggle: A Game for Vocabulary Acquisition. In 12th European Conference on Technology Enhanced Learning, EC-TEL 2017, Tallin, Estonia (pp. 606-609). Springer Verlag. https://doi.org/10.1007/978-3319-66610-5_73

Wright, A., Betteridge, D., \& Buckby, M. (2006). Games for Language Learning. Cambridge: Cambridge University Press.

Zhang, H., Song, W., \& Burston, J. (2011). Reexamining the Effectiveness of Vocabulary Learning Via Mobile Phones. TOJET: The Turkish Online Journal of Educational Technology, 10(3), 203-214. Retrieved from https://eric.ed.gov/?id=EJ944968 
English Language in Focus (ELIF), 2(2), 79-86. https://jurnal.umj.ac.ílindex.php/ELIF 